\title{
TYPHOON TURNING ATLAS
}


This page intentionally left blank 


\section{TYPHOON TURNING ATLAS}

\section{Weihong Qian Xiaolong Shan Haoyuan Liang}

Peking University, China 


\section{Published by}

World Scientific Publishing Co. Pte. Ltd.

5 Toh Tuck Link, Singapore 596224

USA office: 27 Warren Street, Suite 401-402, Hackensack, NJ 07601

UK office: 57 Shelton Street, Covent Garden, London WC2H 9HE

\section{Library of Congress Cataloging-in-Publication Data}

Qian, Weihong

Typhoon turning atlas / Weihong Qian, Peking University, China, Xiaolong Shan, Peking University, China, Haoyuan Liang, Peking University, China.

pages $\mathrm{cm}$

Includes bibliographical references and index.

ISBN 978-9814531818 (pbk. : alk. paper)

1. Typhoons--Tracks--Observations. 2. Typhoons--Forecasting. 3. Cyclones--Tropics--Forecasting. 4. Decomposition method. I. Shan, Xiaolong, author. II. Liang, Haoyuan, author. III. Title.

QC948.Q253 2014

$551.55 ' 20916460223--d c 23$

2013023792

\section{British Library Cataloguing-in-Publication Data}

A catalogue record for this book is available from the British Library.

Copyright (C) 2014 by World Scientific Publishing Co. Pte. Ltd.

All rights reserved. This book, or parts thereof, may not be reproduced in any form or by any means, electronic or mechanical, including photocopying, recording or any information storage and retrieval system now known or to be invented, without written permission from the publisher.

For photocopying of material in this volume, please pay a copying fee through the Copyright Clearance Center, Inc., 222 Rosewood Drive, Danvers, MA 01923, USA. In this case permission to photocopy is not required from the publisher.

Typeset by Stallion Press

Email: enquiries@stallionpress.com 


\section{Preface}

Typhoons, or severe tropical cyclones, with most destructive forces are frequently formed in the South China Sea (SCS) to the western Pacific regions. Typhoons generally move westwards or northwestwards in summer and autumn, following the steering flows associated with the dominant Pacific subtropical high. But, there are often some unusual tracks, turning to the left and/or to the right for one or more times. It is difficult to forecast whether, when, and where the turning occurs based on the traditional synoptic charts and numerical weather forecast model products, because atmospheric variables include multiscale physical components and observational/model errors. Typhoon Turning Atlas provides an additional tool to deal with the problem. The global atmospheric variables of observations and model products can be decomposed into four components: (i) the zonal-averaged symmetric climate, (ii) the asymmetric climate (monsoon troughs), (iii) the zonal-averaged anomaly, and (iv) the synoptic-scale anomaly (including anomalous anti-cyclonic systems and anomalous vortices). This atlas, with thousands of plots, covers important information of 330 historical typhoons occurring in the last three decades in the period of 1979-2011 and demonstrates how the typhoons' motions and intensities were influenced by climatic monsoon troughs and anomalous vortices, respectively.

Classification of the positions from tropical disturbance to typhoon's peak intensity as well as diagnostic method of typhoon motions in this atlas will be surely useful as a good reference for researchers and forecasters in the practice of typhoon prediction. The decomposition method used in this atlas demonstrates how to extract useful information from observations (or model products), which is unlike most mathematical decompositions based on orthogonal basis functions, such as spherical harmonic expansion and empirical orthogonal functions. The atlas consists of seven chapters as follows.

The principle and method of physical decomposition of atmospheric variables, as well as some distribution features of typhoons occurring in the western Pacific and the SCS are described in Chapter 1. In order to understand this atlas, three typhoons with unusual motions and intensity changes are also illustrated as examples in this chapter.

In Chapter 2, typhoon motions without obvious turning are divided into five sections according to their geneses in the SCS, intensity peaked in the SCS, the Philippines, the east seas of China, and the western Pacific, respectively. Typhoons achieving their peak intensities in the SCS, the Philippines, the equatorial Pacific, and the tropical Pacific are illustrated in Chapter 3. Typhoons generated in the Philippines, the equatorial western Pacific, the equatorial central Pacific, and the tropical Pacific and also achieving their peak intensities in the Philippines are shown in Chapter 4. Most typhoons with their peak intensities located in the Taiwan area but generated in the equatorial western Pacific, the equatorial central Pacific, the tropical western Pacific, and the tropical central Pacific are given in Chapter 5. Some typhoons with their intensities peaked in the east seas of China but generated in the equatorial western Pacific, the equatorial central Pacific, the tropical western Pacific, the east seas of China, and the Northwest Pacific are plotted in Chapter 6. Typhoons with their intensities peaked in the equatorial Pacific and in the Northwest Pacific, typhoons generated in the western/central Pacific and entered the east seas of China, as well as twin typhoons and complex tracks of typhoons are described in Chapter 7. 
We would like to thank Professor Chou Jifan for his useful suggestions and Dr Zhang Sheng for his revision to the atlas. This work is supported by the National Natural Science Foundation of China (41375073).

Weihong Qian 28 December 2012 


\section{Contents}

Preface

Chapter 1: Variable Decomposition 1

1.1. Typhoons in the Northwest Pacific and the South China Sea . . . . . . . . . . . . . . 1

1.2. Decomposition Principles . . . . . . . . . . . . . . . . . . . . . . . 2

1.3. Statistical Tracks . . . . . . . . . . . . . . . . . . . . . . . . . 5

1.4. Unusual Motions of Three Typhoons . . . . . . . . . . . . . . . . . . . . . . . . . 8

1.5. Climatic Monsoon Troughs . . . . . . . . . . . . . . . . . . . . . . . . . . . . . 22

1.6. Two Close Tropical Cyclones . . . . . . . . . . . . . . . . . . . . . . . . . . . . . 29

References . . . . . . . . . . . . . . . . . . . . . . . 35

Chapter 2: Typhoons Without Obvious Turning Motions 37

2.1. Geneses in the South China Sea and the Philippines . . . . . . . . . . . . . . . . . . 37

2.2. Intensity Peaked in the South China Sea . . . . . . . . . . . . . . . . . . . . . . . 49

2.3. Intensity Peaked in the Philippines . . . . . . . . . . . . . . . . . . . . . . . . . . 76

2.4. Intensity Peaked in the East Seas of China . . . . . . . . . . . . . . . . . . . . . . 109

2.5. Intensity Peaked in the Western Pacific . . . . . . . . . . . . . . . . . . . . . . . . 131

Chapter 3: Intensity Peaked in the South China Sea 151

3.1. Geneses in the South China Sea . . . . . . . . . . . . . . . . . . . . . . . . . . 151

3.2. Geneses in the Philippines . . . . . . . . . . . . . . . . . . . . . . . . . . . . 166

3.3. Geneses in the Equatorial Pacific . . . . . . . . . . . . . . . . . . . . . . . . . . . 171

3.4. Geneses in the Tropical Pacific . . . . . . . . . . . . . . . . . . . . . . . . . . . . 177

Chapter 4: Intensity Peaked in the Philippines 195

4.1. Geneses in the Philippines . . . . . . . . . . . . . . . . . . . . . . . . . . . . . . 195

4.2. Geneses in the Equatorial Western Pacific . . . . . . . . . . . . . . . . . . . . . . . 198

4.3. Geneses in the Equatorial Central Pacific . . . . . . . . . . . . . . . . . . . . . . . 213

4.4. Geneses in the Tropical Pacific . . . . . . . . . . . . . . . . . . . . . . . . . . . 235

Chapter 5: Intensity Peaked in the Taiwan Area 253

5.1. Geneses in the South China Sea . . . . . . . . . . . . . . . . . . . . . . . . . . 253

5.2. Geneses in the Philippines . . . . . . . . . . . . . . . . . . . . . . . . . . . 256

5.3. Geneses in the Equatorial Western Pacific . . . . . . . . . . . . . . . . . . . . . . . 262

5.4. Geneses in the Equatorial Central Pacific . . . . . . . . . . . . . . . . . . . . . . 267

5.5. Geneses in the Tropical Western Pacific . . . . . . . . . . . . . . . . . . . . . . . . 271

5.6. Geneses in the Tropical Central Pacific . . . . . . . . . . . . . . . . . . . . . . . . 291

Chapter 6: Intensity Peaked in the East Seas of China 297

6.1. Geneses in the Equatorial Western Pacific . . . . . . . . . . . . . . . . . . . . . . 297

6.2. Geneses in the Equatorial Central Pacific . . . . . . . . . . . . . . . . . . . . . . . 301

6.3. Geneses in the Tropical Western Pacific . . . . . . . . . . . . . . . . . . . . . . . 309 
6.4. Geneses in the East Seas of China . . . . . . . . . . . . . . . . . . . . . . . 326

6.5. Geneses in the Northwest Pacific . . . . . . . . . . . . . . . . . . . . . . . . . . 333

Chapter 7: Intensity Peaked in the Pacific 345

7.1. Intensity Peaked in the Equatorial Pacific . . . . . . . . . . . . . . . . . . . . . . . 345

7.2. Intensity Peaked in the Northwest Pacific . . . . . . . . . . . . . . . . . . . . . . . 359

7.3. Geneses in the Western Pacific and Entering the East Seas of China . . . . . . . . . . 382

7.4. Geneses in the Central Pacific and Entering the East Seas of China . . . . . . . . . . . 386

7.5. Twin Typhoons . . . . . . . . . . . . . . . . . . . . . . . . . . . . . 406

7.6. Complex Tracks . . . . . . . . . . . . . . . . . . . . . . . . . . . . . . . . . . . 423 